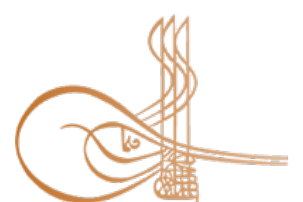

www.turkishstudies.net/economy
Turkish Studies - Economics, Finance, Politics

eISSN: 2667-5625

Research Article / Araștırma Makalesi

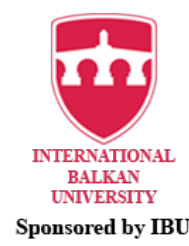

Sponsored by IBU

\title{
Örgütsel Özdeşleşme ve İşten Ayrılma Niyetinin Çalışmaya Tutkunluk Üzerindeki Etkisi
}

\author{
The Impact of Organizational Identification and Turnover Intention on Work Engagement
}

\author{
Oktay Balcı ${ }^{*}$ - Cengiz A $\breve{g}^{* *}$
}

\begin{abstract}
Organizational identification and work engagement are positive behaviours at work. On the one hand there is a collective identify between individual and organization associated with organizational identification and also individuals perform their roles full capacity as cognitive, emotional and behavioral associated with work engagement. On the other hand a possible unidenfication might be strong predictor of turnover intention and lower work engagement. In this study, it was aimed to determine whether the positive or negative perceptions of individuals towards the organization they work for can be converted into work engagement. In this context the answers of such as 'Does the individual who aspires with the organization he / she works for perform his / her job with great enthusiasm?' 'Does this identification provide vigor, dedication and absorption to the individual in doing his / her job?' Is the individual who cannot identify himself/herself with his/her organization wonder whether he/she is trying to spare his efforts and energy?' questions were sought. The population of this study consists of people working in the health sector in the Ümraniye Santral area of Istanbul in 2019. The sample of the study consists of three private hospitals' staff working in this area. The study was carried out with the survey. The scale developed by Mael and Ashforth (1992) was used for the employees' perception of organizational identification and later, Tak and Aydemir (2004) added the turnover intention scale. The Utrecht Work Engagement Scale (UWES), developed by Schaufeli et al. (2002), was used to measure employees' perceptions of work engagement. After correlation and regression analysis, a positive and significant relationship was found between organizational identification and vigor, dedication and absorption, which are the sub-dimensions of the concept of work engagement. Besides, a negative and significant relationship was determined between the turnover intention and vigor- dedication. No strong relationship was found between the turnover intention and absorption. According to the findings of the study, it is possible to say that individuals who identified themselves with their organization will tend to display work engagement in their work. On the other hand work engagement will decrease depending on turnover intention of employees.
\end{abstract}

Structured Abstract: Sigmund Freud first used the concept of identification. Freud defined identification as "the emotional bond that the individual establishes with other people". Then, the concept of identification is

\footnotetext{
* Dr. Millı̂ Eğitim Bakanlığı

PhD, The Ministery of National Education

ORCID 0000-0002-0974-3850

oktaybalci@gmail.com

** Dr. Öğr. Üyesi, Nişantaşı Üniversitesi, İktisadi İdari ve Sosyal Bilimler Fakülesi, Yönetim Bilişim Sistemleri

Asst. Prof. Nişantaşı University, Faculty of Economics, Administrative and Social Science, Management Information Systems

ORCID 0000-0003-3610-492

cengizag@gmail.com

Cite as/ Atıf: Balcı, O. \& Ağ, C. (2020). Örgütsel özdeşleşme ve işten ayrılma niyetinin çalışmaya tutkunluk üzerindeki

etkisi. Turkish Studies - Economy, 15(3), 1195-1213. https://dx.doi.org/10.47644/TurkishStudies.40439

Received/Geliș: 06 January/Ocak 2020

Accepted/Kabul: 20 September/Eylül 2020

Checked by plagiarism software

Copyright (C) INTAC LTD, Turkey

Published/Yayın: 25 September/Eylül 2020

CC BY-NC 4.0
} 
handled in much larger dimensions and types of identification such as mass-nationalism are mentioned (Gautam et al., 2004: 302). Tosun (1981: 145) argued that identification with the organization consists of three elements;

a) The individual believes and accepts the goals and values of the organization,

b) The individual voluntarily fulfills its organizational roles,

c) The individual wishes to continue membership of the organization.

The concept of identification today is a phenomenon that we frequently encounter in our daily lives. For example, "football fan" is a good example of identification. Especially the fact that fanatics accept the insult to their team as if they were made, and in case of defeat they become extremely sad. These are the signs of high identification. Social psychology describes this as "the psychological desire of the individual to belong to a particular group" (social identification) (Drzensky \& Dick, 2009: 2). Thus, Ashforth and Mael (1989: 21) named the individual's perception of belonging to some human clusters as "social identification". Identification refers to the psychological connection between the identity of the individual and the identity of the organization he/she works with (Rikatte and Van Dick, 2005: 491).

In the literature, we see that the concept of organizational identification constitutes the theoretical background of Social Identity Theory. According to this theory, people tend to differentiate themselves and others in various categories such as companionship, religious preference, ethnicity, kinship, business friendship, graduated school, gender and age (Ashforth and Mael, 1969: 20). Self-enhancement and self-esteem motivations are the source of this tendency (Tsuchiya, 2017: 2). The main motive behind the tendency is selfworth. Thus, individuals try to increase their self-values by identifying with social groups (Aronson et al., 2012: 764).

The individual may intend to leave his / her job for economic, organizational and individual reasons. Turnover intention may be voluntary or involuntary $(\mathrm{Ak}, 2018: 1)$ and is the opposite aspect of the concept of identification.

The concept of work engagement was brought to positive organizational behavior by positive psychology. Positive psychology focuses on the happiness and well-being of the individual. It emphasizes the positive characteristics of the individual. In other words, positive psychology is concerned with a pleasant, full and meaningful life (Carr, 2016: 11). Peterson et al. (2005: 25) argued that enjoyment, occupation, and meaning in life are important milestones on the road to happiness. With this aspect, work engagement comes forward to us as a remarkable concept. The concept of "passion" that forms the basis of this behavior is again taken from positive psychology and expresses the positive actions that the individual adds to his personal life. Schaufeli and Bakker (2004: 5) described engagement as the individual's level of work-related mind, characterized by vigor, dedication and absorption. Work engagement in the literature is a three-dimensional concept. These are vigor, dedication and absorption. Vigor is the behavioral, dedication is the emotional, and absorption is the cognitive dimension of work engagement (Bakker ve Demerouti, 2008:210).

Although there is no single theory that forms the theoretical background of the concept of work engagement, there are some approaches in the literature. Kahn (1992: 340) argued that with the work engagement, the individual meets the needs of meaningfulness, psychological security and usefulness. Another theoretical background of the concept of work engagement is the job-demans resources model. According to this theory, the individual's unique resources (psychological capital) and the wealth of business resources must match. This causes more energy, courage and focus to work in the individual (Schaufeli, 2013: 16).

Organizational identification and work engagement are positive behaviours at work. On the one hand there is a collective identify between individual and organization associated with organizational identification and also individuals perform their roles full capacity as cognitive, emotional and behavioral associated with work engagement. On the other hand a possible unidenfication might be strong predictor of turnover intention and lower work engagement. In this study, it was aimed to determine whether the positive or negative perceptions of individuals towards the organization they work for can be converted into work engagement. In this context the answers of such as 'Does the individual who aspires with the organization he / she works for perform his / her job with great enthusiasm?' 'Does this identification provide vigor, dedication and absorption to the individual in doing his / her job?' Is the individual who cannot identify himself/herself with his/her organization wonder whether he/she is trying to spare his efforts and energy?' questions were sought.

Turkish Studies - Economy, 15(3) 
The population of this study consists of people working in the health sector in the Ümraniye Santral area of Istanbul in 2019. The sample of the study consists of three private hospitals' staff working in this area. The study was carried out with the survey. The scale developed by Mael and Ashforth (1992) was used for the employees' perception of organizational identification and later, Tak and Aydemir (2004) added the turnover intention scale. The Utrecht Work Engagement Scale (UWES), developed by Schaufeli et al. (2002), was used to measure employees' perceptions of work engagement.

After correlation and regression analysis, a positive and significant relationship was found between organizational identification and vigor, dedication and absorption, which are the sub-dimensions of the concept of work engagement. Besides, a negative and significant relationship was determined between the turnover intention and vigor- dedication. No strong relationship was found between the turnover intention and absorption. According to the findings of the study, it is possible to say that individuals who identified themselves with their organization will tend to display work engagement in their work. On the other hand work engagement will decrease depending on turnover intention of employees.

With this research it has been revealed that the individual's the individual's identification with his or her organization or not being able to identify (intention to quit) is the antecedent of work engagement. Organizational identification is a mutual relationship between organization and individual. Because both side will gain social and economic advantages after an identification process. But it shouldn't be forgetten that a mutual relationship depends on mutual performance. Therefore, we proposed some recommendation under the light of literature related our topics.

- $\quad$ Actions should be taken to increase the reputation of the organization. The individuals tends to work in a reputable company to increase their dignity.

- The organization should demonstrate practices that distinguish it from other organizations. High discrimination results in high identification.

- $\quad$ The organization should employ individuals who are identified with their mission and vision.

- $\quad$ The organization should pay attention to the overlap of the individual's rational demands and business resources in the selection of human resources.

- The organization should adopt a participatory management approach.

- The organization should treat the individual as a social entity, not an economic one.

- The organization should create an organizational climate and cultural environment in which the individual can express himself physically and spiritually.

- The organization should give the individual the opportunity to improve his career. Career opportunities should be based on objective criteria.

- $\quad$ Trust should be established between the manager and the employee within the organization.

- $\quad$ There should be no compromise from organizational justice. Equal pay for equal work should

be ensured.

- A system should be established in which talented individuals can develop their skills and realize themselves. be adopted.

- Leaders who can coach, inspire, motivate employees in organizational management should

Despite the sufficient available researches on the topic of organizational identificiation and turnover intention, there is still a considerable gap about positive organizational behavior and its relationship with work engagement. We thought that the gap we mentioned before was filled by this research.

Keywords: Organizational identification, work engagement, turnover intention

Öz: Özdeşleşme ve çalışmaya tutkunluk kavramları işte pozitif davranışlardır. Özdeşleşme ile birey ile örgütü arasında kolektif bir kimlik oluşurken; çalışmaya tutkunluk ile birey bilişsel, duygusal ve davranışsal olarak tam kapasite işinin başında sayılmaktadır. Öte yandan bireyin örgütü ile özdeşleşmemesi onda işten ayrılma niyeti ve çalışma isteksizliği oluşturabilir. Bu araştırmada bireylerin çalıştığı örgüte karşı olumlu veya olumsuz algılarının, çalışmaya tutkunluğa dönüştürülüp dönüştürülemeyeceği tespit edilmek istenmiştir. Bu bağlamda 'Çalıştı̆̆ı örgüt ile kendini özleştiren birey acaba işini de büyük bir aşkla mı icra etmektedir?','Özdeşleştirme bireye işini yaparken canlılık, adanmışlık ve odaklanma sağlamakta mıdır?','Kendini örgütü ile 
özdeşleştiremeyen birey çabalarını ve enerjisini örgütüne esirgemekte midir? 'gibi sorularına yanıt aranmıştır. Bu araştırmanın evrenini 2019 yılında İstanbul'da Ümmraniye Santral bölgesinde sağlık söktöründe görev yapan kişiler oluşturmaktadır. Araştırmanın örneklemini ise bu bölgede bulunan üç özel hastahanenin çalışanlarından oluşmaktadır. Veri toplamak için anket kullanılmıştır. Çalışanların "örgütsel özdeşleşme” algılarını ölçmek için Mael ve Ashforth (1992) tarafından geliştirilen ve daha sonra Tak ve Aydemir (2004) tarafından "işten ayrılma niyeti" boyutu eklenen ölçek kullanılmıştır. Çalışanların, çalışmaya tutkunluk algılarını ölçmek için Schaufeli ve diğerleri (2002) tarafından geliştirilen Utrecht Work Engagement Scale (UWES) ölçeği kullanılmıştır. Yapılan korelasyon ve regresyon analizinden sonra "örgütsel özdeşleşme" ile "çalışmaya tutkunluk" kavramının alt boyutları olan "canlılık" "odaklanma" ve "adanmışlık" arasında pozitif ve anlamlı bir ilişki tespit edilmiştir. Ayrıca "işten ayrılma niyeti” ile "canlılık” ve "adanmışlık” arasında beklenildiği üzere negatif ve anlamlı ilişki tespit edilirken; "işten ayrılma niyeti” ile "odaklanma” boyutu arasında herhangi bir ilişki tespit edilmemiştir. Araştırmanın sonuçlarına göre kendini örgütü ile özdeşleşmiş bireylerin çalışmaya tutkun olmaya eğimli olacaklarını söylemek mümkündür. Öte yandan çalışmaya tutkunluk çalışanın işten ayrılma niyeti ile azalma göstermektedir.

Anahtar Kelimeler: Örgütsel özdeşleşme, çalışmaya tutkunluk, işten ayrılma niyeti.

\section{Giriş}

\section{1 Örgütsel Özdeșleşme}

Özdeşleşme kavramını ilk olarak Sigmund Freud kullanmıştır. Freud özdeşleşmeyi "Bireyin diğer insanlarla kurduğu duygusal bağ" olarak tanımlamıştır. Ardından özdeşleşme kavramı çok daha geniş boyutlarda ele alınmış ve kitle-ulusalcılık gibi özdeşleşme tiplerinden söz edilmiştir (Gautam ve diğ. 2004:302). Nihayet Patchen (1970) özdeşleşme kavramının mahiyetini üç madde altında toplamıştır. İlki özdeşleşme ile birlikte birey örgütü ile dayanışma içinde olduğunu düşünmektedir. İkincisi; birey örgütüne tutumsal ve davranışsal olarak destek vermeye eğilimlidir. Üçüncüsü ise birey, diğer grup üyeleri ile aynı şeyleri paylaşmanın kıvancı ve bilinci içerisindedir (akt. Witting, 2006:1). Aynı şekilde Tosun (1981:145) örgütle özdeşleşmenin üç öğeden oluştuğunu ileri sürmüştür;

a) birey, örgütün amaç ve değerlerine inanır ve kabul eder,

b) birey, örgütsel rollerini gönüllü olarak yerine getirir,

c) birey, örgüt üyeliğini devam ettirme isteği içindedir.

Bugün özdeşleşme kavramı günlük hayatımızda da çok sık karşıllaştığımız bir olgudur. Sözgelimi "futbol taraftarlığı" özdeşleşmeye yerinde bir örnek sayılır. Özellikle fanatiklerin tuttukları takıma yapılan hakareti kendilerine yapılmış gibi kabul etmeleri ve yenilgi durumunda aşırı üzüntüye düşmeleri yüksek derecede özdeşleşme belirtileridir. Sosyal psikoloji bunu "bireyin psikolojik olarak kendini belirli bir gruba ait olma isteği "(sosyal özdeşleşme) olarak tarif etmektedir (Drzensky ve Dick,2009:2). Nitekim Ashforth ve Mael (1989:21) bireyin, bazı insan kümelerine kendisini ait olma algısına "sosyal özdeşleşme" adını vermiştir. Bu bağlamda sözgelimi "A Firması çalışanı olmaktan gurur duyarım" diyen biri sosyal özdeşleşmeyi gerçekleştirmiş sayılabilir. Örgütsel özdeşleşme kavramı ise daha farklı olarak özellikle bireyin çalıştığı örgüt ile ilişkilerine yoğunlaşmaktadır. Özdeşleşme, bireyin kimliği ile çalıştığı örgütün kimliği arasındaki psikolojik bağ1 ifade etmektedir (Rikatte ve Van Dick, 2005:491). Örgütsel özdeşleşme sonucunda, bireyin çalıştığı örgütün niteliklerini, başarılarını, hayal kırıklıklarını ve de yazgısını kendi değerleri olarak görmesi ve paylaşması söz konusudur (Mael ve Tetrick, 1992:813). Nitekim Bergami ve Bagozzi (2000:556) örgütsel özdeşleşmeyi bireyin kimliği ile örgütün kimliğinin örtüşmesi olarak betimlemiştir. Benzer şekilde Dutton ve diğerleri (1994:239) ise örgütsel özdeşleşmeyi bireyin kendisini çalıştı̆̆ örgüt ile aynı özelliklere sahip olduğuna inanma derecesi olarak tarif etmiştir. Bu yüzden özdeşleşme sürecinde birey kolektif bir bilinçle kendine 'Biz kimiz?','Örgütteki kimliğim 
nedir?','Örgütüm ile ilgili kendimi nasıl algılıyorum?' türü sorular sormaktadır (Solomon ve Casey, 2017:93).

Alan yazında örgütsel özdeşleşme kavramının kuramsal altyapısını Sosyal Kimlik Kuramının oluşturduğunu görmekteyiz. Bu kurama göre insanlar kendilerini ve diğerlerini takımdaşlık, dini tercih, etnik köken, akrabalık, iş arkadaşlı̆ıı, mezun olunan okul, cinsiyet ve yaş gibi çeşitli kategorilerde ayırma eğilimindedir (Ashforth ve Mael, 1969:20). Bu eğilimin kaynağını bireylerin kendini geliştirme (self-enhancement) ve kendine saygı (self-esteem) motivasyonları oluşturmaktadır (Tsuchiya, 2017:2). Eğilimin altında yatan ana güdü ise benlik değeridir. Böylece bireyler benlik değerlerini, sosyal gruplarla özdeşleşmek vasıtasıyla artırmaya çalışmaktadırlar (Aronson ve di $\breve{g}$. 2012:764).

Sosyal Kimlik Kuramının temelini Tajfel ve diğerlerinin (1971:149) "minimal grup deneyine" dayanmaktadır. Deneyde birbirini daha önce hiç tanımayan katılımcılar rastgale gruplara ayrılmıştır. Deney yöneticisi katılımcılara estetik tercihlerine göre -Klee ve Kandinsky severlerolmak üzere iki gruba ayrıldıkları söylemiştir. Fakat bazı durumlarda kullanılan resimler aynı ressama aittir ve bunu katılımcı bilmiyordur. Gruplar oluşturulduktan sonra katılımcılara kendi grup ve diğer grup üyelerine maddi ödül dağıtacakları bir görev verilmiştir. Fakat katılımcılar ödülleri dağıtırken dürüst bir dağıtım yapmamış, kendi iç grup üyelerine daha fazla ödül vererek ayrımcılık yapmışlardır (Spears ve Otten, 2012:162). Araştırma sonunda insanları rastgele gruplara ayırmanın dahi tarafgirliğin ortaya çıkmasına yeteceği gibi sansasyonel bir düşünce ortaya çıkmıştır (Eniç, 2019:103).

Sosyal Kimlik Kuramına göre birey, çoğu zaman sosyal bir grubun üyesi olarak hareket etmektedir. Demirtaş (2003:129) Sosyal kimlik kuramını dört temel varsayımla açıklamıştır:

-Bireyler, kendileri içinde bulundukları grubu dikkate alarak tanımlar ve böylece sosyal bir kimlik oluştururlar.

-Bireyler, diğer grupları dikkate alarak kendi grubunu değerlendirir ve böylece sosyal bir karşılaştırma yaparlar (Van Dick ve diğ., 2004:3).

-Sosyal karş1laştırma bireyin kendi grubunu, diğer gruplarla karşılaştırma sürecidir. Birey sosyal karşılaştırma yaparken içinde bulunduğu grubu kayırma ve diğer grupları küçük görme eğilimi gösterir. Böylece grup kayırmacılığı ortaya çıkmakta (Demirtaş, 2003:129) ve neticede bireylerde "biz" ve" onlar "algisı oluşmaktadır (Spears ve Otten, 2012:166). Sözgelimi Afrika yerlileri veya Amerika'daki eski kızıldereliler kendilerini diğer kabilelerden ayırt etmek için özgün giyinme ve yüzlerini boyama vasıtasıyla sosyal kimliklerini öne çıkarmışlardır. Aynı bir zamanlar Amerika'da ortaya çıkan Klu Klux Klanlar da başlarına çuval geçirerek ve uzun beyaz elbiseler giyerek bireysel kimliklerini sıfırlayıp, sosyal kimliklerini ortaya koymuşlardır.

-Sosyal karşılaştırma neticesinde bireyin içinde olduğu grup, tahammül edilemeyecek derecede olumsuz ise birey ya var olan gruptan ayrılmaya ya da olumlu sosyal kimliğine tekrar kavuşmak için aynı grup içinde kalmayı tercih etmektedir (Tafjel ve Turner, 1986:284).

Alan yazında örgütsel özdeşleşmenin bilişsel, duyuşsal, değerlendirici ve davranışsal olmak üzere dört ayrı boyutu olduğu görülmektedir (Aliyev, 2014:74). Bilişsel boyut, bireyin belli bir gruba üye olduğuna dair bilgidir. Duyuşsal boyut, bireyin içinde olduğu gruba beslediği duygusal bağdır. Değerlendirici boyut, gruba içeri ve dışarıdan atfedilen değerdir. Davranışsal boyut ise bireyin özdeşleşme sonucu belli davranışlar sergilemesidir (Mamatoğlu, 2010:83).

\section{2 İşten Ayrılma Niyeti}

Birey ekonomik, örgütsel ve bireysel nedenlerden dolayı çalıştı̆̆ işinden ayrılmaya niyetlenebilir. İşten ayrılma niyeti, gönüllü veya gönülsüz şeklinde olabilir (Ak, 2018:1). Ayrılma niyeti, özdeşleşme kavramının zıt yönüne işaret etmektedir. Sözgelimi Tuna ve Yeşiltaş (2014) 
turizm sektöründe yaptıkları araştırma sonucunda işten ayrılma ile örgütsel özdeşleşme arasında negatif ilişki tespit etmiştir. Benzer şekilde, Polat ve Meydan (2010) özel sektör çalışanları üzerinde yaptıkları araştırmada örgütsel özdeşleşme ile işten ayrılma niyeti arasında negatif ilişki tespit etmiştir. Ayrıca Demircioğlu ve Giritli (2015) inşaat sektöründe yaptıkları araştırmada örgütsel özdeşleşmenin işten ayrılmayı cesaretlendirdiğini ifade etmiştir. Öte yandan Schaufeli ve Bakker (2004) çalışmaya tutkunluğun iş kaynakları ile işten ayrılma niyeti arasında aracı değişken olduğunu tespit etmiştir. Kaynakların yüksek potansiyeli, yüksek seviyede çalışmaya tutkunluğu ve düşük işten ayrılma niyetini ortaya koymuştur. Nihayet Alfes ve diğerleri (2013) hizmet sektöründe yaptıkları araştırmada işten ayrılma niyeti ile çalışmaya tutkunluk arasında anlamlı ve negatif ilişki tespit etmişlerdir.

\section{3 Çalışmaya Tutkunluk}

Çalışmaya tutkunluk kavramı pozitif psikoloji tarafından pozitif örgütsel davranışa kazandırılmıştır. Pozitif psikoloji bireyin mutluluk ve esenliğine yoğunlaşmaktadır. Bireyin olumlu özelliklerini ön plana çıkarmaktadır. Bir başka deyişle pozitif psikoloji keyifli, dolu ve anlamlı bir yaşamla ilgilenmektedir (Carr, 2016:11). Peterson ve diğerleri (2005:25) keyif almanın, bir şeylerle meşgul olmanın ve yaşamda anlamın mutluluğa giden yolda önemli kilometre taşları olduğunu ileri sürmüştür. Bu yönüyle çalışmaya tutkunluk dikkat çeken bir kavram olarak önümüze çıkmaktadır. $\mathrm{Bu}$ davranışın temelini oluşturan "tutkunluk" kavramı yine pozitif psikolojiden alınmış ve bireyin kişisel yaşantısına kattığı pozitif edimleri ifade etmektedir. Schaufeli ve Bakker (2004:5) tutkunluğu, bireyin iş ile ilgili zihin düzeyinin canlılık, odaklanma ve adanma ile karakterize olmuş hali olarak tarif etmiştir. Bir anlık veya belirgin bir durumdan ziyade çok daha uzun soluklu bir iradeyi temsil etmektedir. Buna binaen Kahn (1990:694) çalışmaya tutkunluğu insanların çalışma rollerine koşması ve bu rolü yerine getirirken fiziksel, bilişsel ve duygusal olarak tam kapasite çalışması olarak tanımlamıştır. Araştırmacıya göre bireyin kendini ifade edebilmesi çalışmaya tutkunluğun önemli bir boyutudur. Kendini ifade etmek bireyin işyerinde kendi olabilmesi anlamına gelmektedir. Kendi kimliğini kendi rolü çerçevesinde ortaya koymasıdır.

Bakker ve diğerleri (2014:394) çalışmaya tutkunluğu, bireyin örgüte kazandırdığg pozitif enerji olarak kabul etmiştir. İşgörenin çalışmaya tutkun olması temelde üç yönde örgüte enerji sağlamaktadır. Bunlar çalışanın yüksek örgütsel bağlılı̆̆ı, çalışanın ilave rol davranışı gösterme eğilimi ve iş tatminidir (Schaufeli, 2012:3). Alan yazında çalışmaya tutkunluk aynı zamanda tükenmişliğin anti tezi olarak kabul edilmektedir. Zira çalışmaya tutkun insanlar tükenmiş insanların aksine işyerinde daha enerjik ve etkindir (Schaufeli, 2012:4). Çalışmaya tutkunluk tamamen bir kişilik özelliği olarak kabul edilmektedir. Robinson ve diğerleri (2004:6) çalışmaya tutkun insanları örgütü ile özdeşleşen, örgütüne inanan ve örgütün performansını iyiliştirmek için firsat kollayan kişiler olarak tarif etmiştir.

Alan yazında çalışmaya tutkunluk üç boyutlu bir kavram olarak karşımıza çıkmaktadır. Bunlar canlılık, adanma ve odaklanmadır.'Canlılık' çalışmaya tutkunluğun davranışsal boyutunu,'Adanma' duygusal boyutunu ve 'Odaklanma' ise bilişsel boyutunu oluşturmaktadır. 'Canlılık' bireyin çalışırken fiziksel ve ruhsal olarak yüksek enerji sarf etmesini ifade etmektedir (Bakker ve Demerouti, 2008:210). Birey zor zamanlarda bile istikrarını bozmayan bir enerji ile çalışmaya ve emek harcamaya gönüllü durumdadır.' Adanma' ise bireyin işine önem atfetmesini, işini yaparken hissettiği şevki ve gururu temsil etmektedir. Birey zorluklara karşı dirençlidir (Schaufeli ve diğ., 2002:74) ve işi ile arasında güçlü bir duygusal bağ vardır. Dahası işiyle hem kendine hem de yüksek bir amaca hizmet ettiğini düşünmektedir (Bakker ve diğ., 2008: 188).'Odaklanma' ise bireyin çalışırken kendini kaybetmesi ve işine yoğunlaşmasını ifade etmektedir. Burada tabiri caizse birey tam bir akış halindedir ve çalışırken zamanın nasıl geçtiğini anlamamaktadır (Schaufeli ve diğ.,2002:75). 
Çalışmaya tutkunluk kavramının kuramsal alt yapısını oluşturan tek bir kuram olmamasına rağmen alan yazında bazı yaklaşımlar mevcuttur. Kahn (1992:340) çalışmaya tutkunluk ile bireyin anlamlılık, psikolojik güvenlik ve işe yararlık ihtiyaçlarını karşıladığını ileri sürmüştür. Birey kişiliğine uygun bir görev icra ederek yaşamına anlam katmaktadır. Ayrıca içinde bulunduğu sosyal çevrenin onda oluşturduğu psikolojik rahatlık (güven) içindedir. Kişisel kaynaklarını sözgelimi fiziksel enerjisini işine aktararak işe yaradığını düşünmektedir. Çalışmaya tutkunluk kavramının bir diğer kuramsal altyapısını çalışma kaynakları modeli oluşturmaktadır. Bu kurama göre bireyin kendine özgü kaynakları (psikolojik sermaye) ile iş kaynaklarının zenginliği uyuşmak zorundadır. Bireyde böylece çalışmak için daha çok enerji, cesaret ve odaklanma oluşmaktadır (Schaufeli, 2013:16).

\section{Araştırmanın Yöntemi}

\subsection{Araştırmanın Amacı ve Önemi}

$\mathrm{Bu}$ araştırmada bireyin çalıştığı örgüte karşı olumlu veya olumsuz algılarının, çalışmaya tutkunluğa dönüştürülüp dönüştürülemeyeceği tespit edilmek istenmiştir. Bu bağlamda "Çalıştığ1 örgüt ile kendini özleştiren birey acaba işini de büyük bir aşkla mı icra etmektedir?", "Özdeşleştirme bireye işini yaparken canlılık, adanmışlık ve odaklanma sağlamakta mıdır?”, “ Kendini örgütü ile özdeşleştiremeyen birey çabalarını ve enerjisini örgütüne esirgemekte midir? " gibi sorulara yanıt aranmıştır.

\subsection{Araştırmanın değişkenleri ve hipotez geliştirme}

Tutkunluk kavramı iş tatmini, işi benimseme, örgütsel bağlılık ve iş performansı ile yakından ilgilidir (Schaufeli, 2013). Özdeşleşme ise bireyin örgütsel rollerini gönüllü olarak yapması ve örgüt üyeliğinin sürdürme isteğini ifade etmektedir. Örgütsel özdeşleşme ile birey, örgütü ile bilişsel ve duygusal bir bağ oluşturmuştur (Edwards ve Peccei, 2007). Öte yandan özdeşleşme hem birey hem de örgüt tarafından istenen bir olgudur. Nitekim örgütsel özdeşleşme sonucunda birey ile örgütü arasında kolektif bir kimlik oluşmaktadır. Sözgelimi Ashforth ve Mael (1989) örgütsel özdeşleşme sonucunda örgütte pozitif bir iklim oluşacağını ve bunun da verimliliği artıracağını ileri sürmüştür. Benzer şekilde Mamatoğlu (2010) örgütsel özdeşleşme ile birlikte örgüt içinde pozitif bir iklim oluşacağı ve bununda örgüt içinde mutluluğu ve verimliliği artıracağını ifade etmiştir. Lee ve diğerleri (2015) örgütsel özdeşleşen bireyin kolektif amaçlara ulaşmak için katkı sağlayacağını, ilave performans göstereceğini ve davranışlarında pozitif yönde gelişmeler olacağını söylemiştir. Robinson ve diğerleri (2004) ise çalışmaya tutkun insanların özellikleri arasında bireyin örgütle özdeşleşmesini de belirtmiştir. Tosun (1981) örgütü ile özdeşleşmiş bireyin işine tutku ile bağlanmasının bekleneceğini söylemiştir. Öte yandan Alfes ve diğerleri (2013) yaptıkları araştırmada işten ayrılma niyeti ile çalışmaya tutkunluk arasında anlamlı ve negatif ilişki tespit etmişlerdir. Bu bağlamda araştırmamızın modeli ve hipotezleri Şekil 1'deki gibi kurulmuştur. 


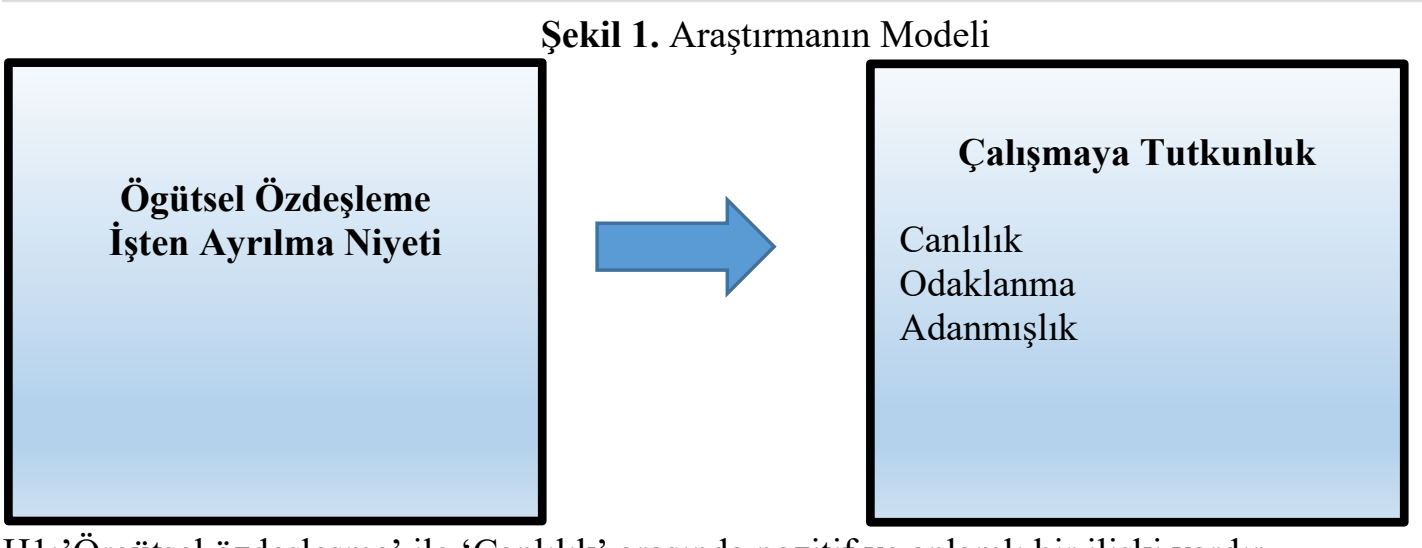

H1:'Örgütsel özdeşleşme' ile 'Canlılık' arasında pozitif ve anlamlı bir ilişki vardır.

H2:'Örgütsel özdeşleşme' ile 'Odaklanma' arasında pozitif ve anlamlı bir ilişki vardır.

H3:'Örgütsel özdeşleşme' ile 'Adanmışlık' arasında pozitif ve anlamlı bir ilişki vardır.

H4:'İşten ayrılma niyeti' ile 'Canlılık' arasında negatif ve anlamlı bir ilişki vardır.

H5:' Issten ayrılma niyeti' ile 'Odaklanma' arasında negatif ve anlamlı bir ilişki vardır.

H6: 'Isşten ayrılma niyeti' ile 'Adanmışlık' arasında negatif ve anlamlı bir ilişki vardır.

\subsection{Araştırmanın Evreni ve Örneklemi}

Araştırmanın evreni 2019 yılında İstanbul Anadolu yakası Ümraniye İlçesi Santral bölgesinde bulunan özel hastanelerde görev yapan sağlık çalışanları oluşturmaktadır. Bu bölge bulunan üç özel hastanede toplam 205 kişi çalışmaktadır. Araştırmanın örneklemi ise bu hastanelerde görev yapan 138 kişiden oluşmaktadır. Örneklem büyüklügü̈ evren büyüklüğünün \% 67'sine denk gelmektedir. Raosoft örneklem büyüklügü hesaplama kritetine göre ilgili veriler girildiğinde gerekli yeter sayıs1 134 olarak görülmektedir (www.raosoft.com).

\subsection{Veri Toplama Araçları ve Teknikleri}

Bu araştırma örgütsel özdeşleşme ve çalışmaya tutkunluk arasındaki ilişki türünü ve düzeyini saptamaya çalışan ilişkisel tarama modelindedir. Anket ile rastlantısal örneklem metodu kullanılarak veri toplama yolu izlenmiştir. Çalışanların örgütsel özdeşleşme algılarını ölçmek için Mael ve Ashforth (1992) tarafından geliştirilen ve daha sonra Tak ve Aydemir (2004) tarafından "çalışanın işten ayrılma" boyutunu eklenen 12 soruluk ölçek kullanılmıştır. Ölçeğin Türkçe'ye uyarlanması, geçerlik ve güvenirliği Tak ve Aydemir (2004) tarafından yapılmıştır. Çalışanların çalışmaya tutkunluk algılarını ölçmek için Schaufeli ve diğerleri (2002) tarafından geliştirilen Utrecht Work Engagement Scale (UWES) ölçeği ile ölçülmüştür. Ölçeğin Türkçe’ye uyarlanması, geçerlik ve güvenirliliği Turgut (2011) tarafından yapılmıştır.

\subsection{Verilerin Analizi, Bulgular ve Tartışma}

Araştırmada verilerin analizinde SPSS 22.00 istatistik paket programı kullanılmıştır. Ankete katılımcılar tarafindan verilen yanıtlar için (1: kesinlikle katılmıyorum'dan, 5: kesinlikle katılıyorum'a) 1-5 tipi Likert ölçeği kullanılmıştır. Araştırma için 175 adet anket hazırlanmış ve kullanıcılara ulaştırılırmış, bunlardan 151 adedi geri dönmüş ve anket sorularına verilen cevaplar incelendiğinde tam ve eksiksiz olan 138 adedi analize tabi tutulmuştur.

Araştırma sonucunda elde edilen verilere göre katılımcıların demografik özellikleri, katılımcı sayıları ile yüzdeleri ile aşağıdaki tablolarda sunulmaktadır. 
Tablo 1: Araştırmaya Katılanların Cinsiyete Göre Dağılımları

\begin{tabular}{|l|c|c|}
\hline Cinsiyet & Frekans & Yüzde (\%) \\
\hline Erkek & 64 & 46,4 \\
\hline Kadın & 74 & 53,6 \\
\hline Toplam & 138 & 100,0 \\
\hline
\end{tabular}

Tablo 1'de belirtildiği üzere araştırmanın katılımcılarının \%46,4'ü erkek, \%53,6'sı kadın bireylerden oluşmaktadır.

Tablo 2: Araştırmaya Katılanların Eğitimine Göre Dağglımları

\begin{tabular}{|l|c|c|}
\hline Ĕ̆itim & Frekans & Yüzde (\%) \\
\hline Ön Lisans & 36 & 26,1 \\
\hline Lisans & 68 & 49,3 \\
\hline Yüksek Lisans ve Üstü & 34 & 24,6 \\
\hline Toplam & 138 & 100,0 \\
\hline
\end{tabular}

Tablo 2'de görüleceği üzere araştırmaya katılanların \% 26,1'i ön lisans, \%49,3'ü lisans ve $\%$ 24,6'sı yüksek lisans ve üstü eğitim almışlarıdır.

Yukarıda ortaya konulan hipotezlerin test edilmesinde, faktör analizinde bağımlı ve bağımsız değişkenler arasında korelasyon ilişkisinin olup olmadığı sorgulanmaktadır. Bağımlı ve bağımsız değişkenler arasındaki korelasyon ilişkisi arttıkça faktör analizi ile ortaya çıkan sonuçlara olan güven de artma göstermektedir. Araştırmamızın değişkenleri faktör analizine tabi tutulmuştur. P(sign) değeri 0,05'in altında olduğundan Barlett testinin sonucu anlamlıdır. Bu araştırmada, KMO genel kabul gören değer olan 0,5 'in üzerinde çıkmış olup araştırmanın örneklem büyüklügünün yeterli sevide olduğunu göstermektedir. Örgütsel özdeşleşme değişkeninin soruları temel bileşenler yöntemi olan varimax dik döndürme yöntemi kullanarak analize tabi tutulmuştur. Örneklem yeterlik ölçüsü 0,5'nin altında kalan, faktör altında tek kalan, birbirlerine yakın faktör ağırlıkları olan 1,7 ve 8 . sorular analizden çıkarılarak yapılan faktör analizinde öz değerleri 1 ve üzerinde olan iki faktör elde edilmiştir (Özdemir, 2013:314). Tablo 3'de örgütsel özdeşleme değişkeni için güvenilirlik analizleri yapıldığında her iki faktörün 0,70 güvenilirlik düzeyinin üstünde olduğu tespit edilmiştir. Toplam açıklanan varyans \%63,938 olarak bulunmuştur. 
Tablo 3a: Örgütsel Özdeșelme Faktör Analizi Sonuçları

\begin{tabular}{|c|c|c|c|c|}
\hline $\begin{array}{l}\text { Faktörün } \\
\text { Adı }\end{array}$ & Soru İfadesi & $\begin{array}{l}\text { Faktör } \\
\text { Ăğırlıkları }\end{array}$ & $\begin{array}{l}\text { Faktörün } \\
\text { Açıklayıcilığı }\end{array}$ & Güvenilirlik \\
\hline \multirow{5}{*}{ 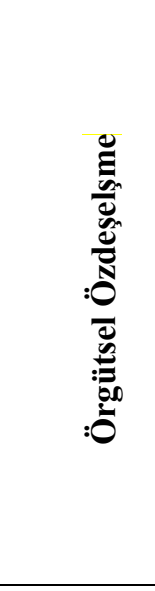 } & $\begin{array}{l}\text { Diğer kişilerin çalıştığım işyeri hakkında ne } \\
\text { düşündükleri benim için önemlidir }\end{array}$ & 0,694 & \multirow{5}{*}{$\% 41,246$} & \multirow{5}{*}{0,845} \\
\hline & $\begin{array}{l}\text { Çalıştığım işyeri hakkında konuşurken } \\
\text { genellikle "biz" ifadesini kullanırım }\end{array}$ & 0,832 & & \\
\hline & $\begin{array}{l}\text { Çalıştığım işyerinin başarısını kendi } \\
\text { başarım gibi hissederim }\end{array}$ & 0,808 & & \\
\hline & $\begin{array}{l}\text { Biri çalıştığım işyeri için övgü dolu sözler } \\
\text { söylediğinde kendime iltifat edilmiş gibi } \\
\text { hissederim }\end{array}$ & 0,771 & & \\
\hline & $\begin{array}{l}\text { Medyada çalıştığım işyerine yönelik bir } \\
\text { eleştiri yer aldığında kendimi kötü } \\
\text { hissederim }\end{array}$ & 0,771 & & \\
\hline \multirow{4}{*}{ 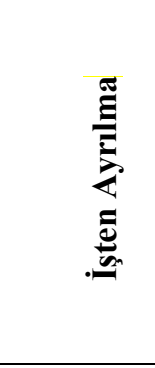 } & $\begin{array}{l}\text { Önümüzdeki yıllarda başka bir işyerinde } \\
\text { çalışmayı düşünüyorum. }\end{array}$ & 0,887 & \multirow{4}{*}{$\% 22,692$} & \multirow{4}{*}{0,780} \\
\hline & $\begin{array}{l}\text { Önümüzdeki } 5 \text { yıl içinde bu işyerinden } \\
\text { ayrılmayı düşünüyorum. }\end{array}$ & 0,859 & & \\
\hline & $\begin{array}{l}\text { Diğer işyerlerinde iş bulma olanağım olup } \\
\text { olmadığına bakıyorum. }\end{array}$ & 0,694 & & \\
\hline & Sık sık işten ayrılmayı düşünüyorum & 0,597 & & \\
\hline \multicolumn{3}{|c|}{ Toplam Açıklanan Varyans } & $\% 63,938$ & \\
\hline \multicolumn{4}{|c|}{ Kaiser-Meyer-Olkin Ölçek Geçerliliği } & 0,744 \\
\hline & & & p değeri & 0,000 \\
\hline
\end{tabular}

Araştırmanın diğer değişkeni olan Çalışmaya Tutkunluk soru grubu için yapılan faktör analizinde bu soru grubunun üç boyuttan oluştuğu ve açıklama varyans oranın \%70,658 olduğu ortaya çıkmıştır $(\mathrm{KMO}=0,838, \mathrm{p}=0,000)$. Çalışmaya Tutkunluk anketinin soru grubundaki $3,11,12$ ve 17. sorular analizden çıkarılarak faktör analizine tabi tutulmuştur. Tablo 3b'de görüleceği üzere elde edilen üç boyutun güvenilirlik analizi sonucunda Cronbach Alfa değerinin 0,7'den yüksek çıkması (canlılık=0,804, odaklanma $=0,840$ ve adanmışlık $=0,869)$ bu üç faktörün iç tutarlığının yüksek olduğunu göstermektedir (Durmuş ve diğ., : 89). 
Tablo 3b: Çalışmaya Tutkunluk Faktör Analizi Sonuçları

\begin{tabular}{|c|c|c|c|c|}
\hline $\begin{array}{l}\text { Faktörün } \\
\text { Adı }\end{array}$ & Soru İfadesi & $\begin{array}{l}\text { Faktör } \\
\text { Ăğırlıkları }\end{array}$ & $\begin{array}{l}\text { Faktörün } \\
\text { Açıklayıcılığı }\end{array}$ & Güvenilirlik \\
\hline \multirow{5}{*}{$\begin{array}{l}\text { 兰 } \\
\text { Ü } \\
\text { Ü }\end{array}$} & İşimi yaparken enerji dolu olurum. & 0,747 & \multirow[b]{3}{*}{$\% 47,389$} & \multirow[b]{3}{*}{0,804} \\
\hline & İşimde kendimi güçlü ve dinç hissederim. & 0,828 & & \\
\hline & $\begin{array}{l}\text { Sabah uyandığımda işe gitmek için istekli } \\
\text { olurum. }\end{array}$ & 0,543 & & \\
\hline & Çok uzun saatler çalışabilirim. & 0,660 & & \\
\hline & $\begin{array}{l}\text { Her şey yolunda gitmese bile işimde daima } \\
\text { sebat ederim. }\end{array}$ & 0,602 & & \\
\hline \multirow{4}{*}{ 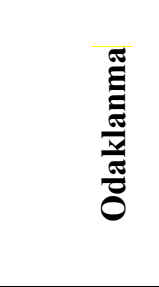 } & Çalışırken işime dalıp giderim. & 0,671 & \multirow{4}{*}{$\% 14,577$} & \multirow{4}{*}{0,840} \\
\hline & Çalışırken yaptığım işe kendimi kaptırırım. & 0,728 & & \\
\hline & $\begin{array}{l}\text { Çalışırken çevremdeki her şeyi } \\
\text { unutuveririm. }\end{array}$ & 0,863 & & \\
\hline & Çalışırken mola vermekte zorlanırım. & 0,737 & & \\
\hline \multirow{4}{*}{ 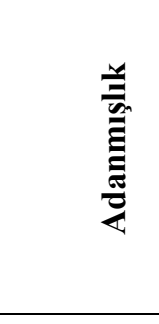 } & $\begin{array}{l}\text { Yaptığım işin anlamlı olduğunu ve bir } \\
\text { amaca hizmet ettiğini düşünüyorum. }\end{array}$ & 0,858 & & \\
\hline & $\begin{array}{l}\text { İşimin ilgi çekici ve gayret gerektiren bir iş } \\
\text { olduğunu düşünüyorum. }\end{array}$ & 0,713 & \multirow{3}{*}{$\% 8,691$} & \multirow{3}{*}{0,869} \\
\hline & Yaptı̆̆ım işle gurur duyarım. & 0,857 & & \\
\hline & İşim bana ilham verir. & 0,683 & & \\
\hline \multicolumn{3}{|c|}{ Toplam Açıklanan Varyans } & $\% 70,658$ & \\
\hline \multicolumn{4}{|c|}{ Kaiser-Meyer-Olkin Ölçek Geçerliliği } & 0,838 \\
\hline & & & & 0,000 \\
\hline
\end{tabular}

Yapılan korelayon analizi neticesinde bağımlı ve bağımsız değişkenlere ait korelasyon katsayı değerleri Tablo 4'de verilmektedir. Korelasyon katsayı değerleri bütün bağımsız ve bağımlı değişkenler arasında birebir ve anlamlı bir ilişkinin olduğunu dair güçlü ilişkiye işaret etmektedir. Ancak, İşten Ayrılma ile Odaklanma boyutlar arasındaki korelasyon ilişkisi anlamlı düzeyde çıkmamıştır. Korelasyon tablosundan görüleceği üzere araştırmanın hipotezlerini oluşturan değişlenler arasında ilişki varlığı tespit edilmiştir. 
Tablo 4: Değişkenler Arasındaki Korelasyon Katsayı Değerleri

\begin{tabular}{|l|c|c|c|c|c|}
\hline Değişkenler & $\mathbf{1}$ & $\mathbf{2}$ & $\mathbf{3}$ & $\mathbf{4}$ & $\mathbf{5}$ \\
\hline Örgütsel Özdeşleşme & $\mathbf{1}$ & & & & \\
\hline İșten Ayrılma &,$- 277^{* *}$ & $\mathbf{1}$ & & & \\
\hline Canlılık &, $435^{* *}$ &,$- 259^{*}$ & $\mathbf{1}$ & & \\
\hline Odaklanma &, $398^{* *}$ &,- 237 &, $593^{* *}$ & $\mathbf{1}$ & \\
\hline Adanmışlı &, $409^{* *}$ &,$- 397^{* *}$ &, $599^{* *}$ &, $455^{* *}$ & $\mathbf{1}$ \\
\hline
\end{tabular}

Literatür incelemesi sonucunda olușturulan kuramsal metinde elde edilen hipotezlerin testi için regresyon analizi yapılmıştır. Örgütsel Özdeşleşme ile Çalışmaya Tutkunluk değişkenlerinin boyutları arasında yapılan regresyon testleri sonuçlarında elde edilen bulgular aşağıdaki tablolarda görülmektedir.

Örgütsel Özdeşleşme bağımlı değişkeni ile Çalışmaya Tutkunluk bağımsız değişkeninin boyutları olan Canlılık, Odaklanma ve Adanmışlık regresyon analizine tabi tutulmuştur.

Tablo 5'de Örgtüsel Özdeşleşme ile Çalışmaya Tutkunluk değişkenin boyutlarından olan Canlılık arasındaki regresyon analizi görülmektedir.

Tablo 5: Örgütsel Özdeşleşme ile Canlılık Arası Regresyon Analizi

\begin{tabular}{|l|l|l|l|}
\hline Bağımsız Değişken & Beta Katsayısı & t Değeri & p Değeri \\
\hline Örgütsel Özdeşleme &, 435 & 3,959 &, 000 \\
\hline
\end{tabular}

Tablo 5'de elde edilen verilere göre, regresyon tablosunda açıkça görüleceği üzere ilk hipotezimizde ifade edilen pozitif yöndeki ilişkinin doğruluğu kanıtlanmaktadır.

H1:" Örgütsel özdeşleşme" ile "Canlılık" arasında pozitif ve anlamlı bir ilişki vardır. $\left(\mathrm{R}^{2}=, 190\right.$, ayarlanmış $\mathrm{R}^{2}=, 177$, p değeri=,000) Desteklenmiștir.

İkinci hipotezin testi edilmesi için Örgütsel Özdeşleşme ile Odaklanma boyutu arasında regresyon analizi yapılmıştır. Sonuçları Tablo 6'da görülmektedir.

Tablo 6: Örgütsel Özdeşleşme ile Odaklanma Arası Regresyon Analizi

\begin{tabular}{|l|l|l|l|}
\hline Bağımsız Değişken & Beta Katsayısı & t Dĕgeri & p Dĕgeri \\
\hline Örgütsel Özdeşleşme &, 398 & 3,551 &, 001 \\
\hline
\end{tabular}

Yukarıdaki korelasyon analizi ve Tablo 6'daki regreyon analizi sonuçlarına göre her ikinci hipotezde ifade edilen pozitif ilşiki doğrulanmıştır. H2:" Örgütsel özdeşleşme" ile "Odaklanma" arasında pozitif ve anlamlı bir ilişki vardır. $\left(\mathrm{R}^{2}=, 158\right.$, ayarlanmış $\mathrm{R}^{2}=, 146$, p değeri=,001) Desteklenmiștir.

Üçüçncü hiptezin test edilmesi için tablo 7'de görüleceği üzere Örgütsel Özdeşleşme ile Adanmışlık boyutu regresyon analizine tabi tutulmuştur.

Tablo 7: Örgütsel Özdeşleşme ile Odaklanma Arası Regresyon Analizi

\begin{tabular}{|l|l|l|l|}
\hline Bağımsız Değişken & Beta Katsayısı & t Değeri & p Dĕgeri \\
\hline Örgütsel Özdeşleşme &, 409 & 3,671 &, 000 \\
\hline
\end{tabular}


Üçüncü hipotezde ifade edilen Örgütsel Özdeşleşme ile Adanmışlık arasındaki pozrif yöndeki ilişki doğrulanmıştır. H3:" Örgütsel özdeşleşme” ile "Adanmışlık" arasında pozitif ve anlamlı bir ilişki vardır. $\left(\mathrm{R}^{2}=, 167\right.$, ayarlanmış $\mathrm{R}^{2}=, 155$, p değeri=,000) Desteklenmiștir.

Daha sonra İşten Ayrılma Niyeti ile Çalışmaya Tutkunluk bağımsız değişkenin Canlılık, Odaklanma ve Adanmışlık boyutları regresyon analizine tabi tutulmuştur. Tablo 8'de İşten Ayrılma Niyeti ile Çalışmaya Tutkunluk boyutlarından olan Canlılık arasındaki regreyon analizinde görüleceği üzere dördüncü hipotezde ifade edilen İşten Ayrılma Niyeti ile Canlılık arasındaki negatif anlamlı ilişki doğrulanmıştır. H4:" İșten ayrılma niyeti" ile "Canlılık" arasında negatif ve anlamlı bir ilişki vardır. $\left(\mathrm{R}^{2}=, 067\right.$, ayarlanmış $\mathrm{R}^{2}=, 053$, p değeri=,032) Desteklenmiștir.

Tablo 8: İşten Ayrılma ile Canlılık Arası Regresyon Analizi

\begin{tabular}{|l|l|l|l|}
\hline Bağımsız Değişkenler & Beta Katsayısı & t Dĕgeri & p Dĕgeri \\
\hline İşten Ayrılma Niyeti &,- 259 & $-2,195$ &, 032 \\
\hline
\end{tabular}

Tablo 9'da görüleceği üzere beşinci hipotezin testi için İşten Ayrılma Niyeti değişkeni ile Çalışmaya Tutkunluk değişikenin alt boyutu olan Odaklanma regresyon analizine tabi tutulmuştır.

Tablo 9: İş̦ten Ayrılma Niyeti ile Odaklanma Arası Regresyon Analizi

\begin{tabular}{|l|l|l|l|}
\hline Bağımsız Değişkenler & Beta Katsayısı & $\boldsymbol{t}$ Değeri & p Değeri \\
\hline İşten Ayrılma Niyeti &,- 237 & $-1,993$ &, 050 \\
\hline
\end{tabular}

Tablo 9'da görüleceği üzere beşinci hipotezde öne sürülen ilişki tam olarak sınır değerlerde oluştuğu için hipotezin desteklenmediği kabul edilmiştir. H5:" İşten ayrılma niyeti" ile "Odaklanma" arasında negatif ve anlamlı bir ilişki vardır. $\left(\mathrm{R}^{2}=, 056\right.$, ayarlanmış $\mathrm{R}^{2}=, 042$, p değeri $\left.=, 050\right)$ Desteklenmemiștir.

Altıncı hipotez olarak ifade edieln son hipotezde ise İşten Ayrılam Niyeti ile Adanmışlık arasındaki ilişki Tablo 10'da görüleceği üzere regreyon analizine tabi tutulmuştur.

Tablo 10: İșten Ayrılma Niyeti ile Odaklanma Arası Regresyon Analizi

\begin{tabular}{|l|l|l|l|}
\hline Bağımsız Değişkenler & Beta Katsayısı & t Değeri & p Değeri \\
\hline İşten Ayrılma Niyeti &,- 397 & $-3,546$ &, 001 \\
\hline
\end{tabular}

Elde edilen veriler doğrultusunda son hipotezde ileri sürülen İşten Ayrılma Niyeti ile Adanmışlık arasında negatif anlamlı ilişki olduğu tespit edimiştir. H6:" İşten ayrılma niyeti” ile "Adanmışlık" arasında negatif ve anlamlı bir ilişki vardır. $\left(\mathrm{R}^{2}=, 158\right.$, ayarlanmış $\mathrm{R}^{2}=, 145, \mathrm{p}$ değeri=,001) Desteklenmiștir.

\section{Tartışma}

Örgütsel özdeşleşme bireyin içinde bulunduğu örgütün amaç ve değerlerini kendi amaç ve değerleri olarak kabul etmesidir. Kendini örgütü vasıtasıyla kimliklendirmesidir. Anketi uyguladığımız çalışma grubunda verilen cevapların ortalamalarının alınması analizi yapıldığında 
örgütsel özdeşleşme boyutunun ortalaması 3,8478 olarak bulunmuştur. Bu da araştırma grubumuzu oluşturan bireylerin işyerleri ile özdeşleşme yönünde eğilim sergilediklerini göstermektedir. Ayrıca grubun işten ayrılma eğilimlerinin ortalamasının 2,6087 değerinde olması araştırma grubumuzda işten ayrılma eğilimin düşük olduğunu göstermektedir. Çalışmaya tutkunluk anket soruları kümesinden oluşan değişkenin boyutlarının ortalamaları alındığında "adanmışlık" boyutunun 4,0942 ortalama ile en yüksek çıktığı görülmektedir. Bunu sırasıyla ve "canlılık" 3, 7681 ve "odaklanma" 3,6754 izlemektedir.

$\mathrm{Bu}$ araştırma ile örgütsel özdeşleşme ve işten ayrılma niyetinin bireyin çalışma tutkusu arasındaki ilişki tespit edilmek istenmiştir. Hipotez olarak özdeşleşme ile çalışmaya tutkunluk arasındaki pozitif, işten ayrılma niyeti ile çalışmaya tutkunluk arasında negatif ilişki olduğu üzerine kurulmuştur. Araştırma sonucunda "örgütsel özdeşleşme" ile "çalışmaya tutkunluk" kavramının alt boyutları olan "canlılık" "odaklanma" ve "adanmışlık" arasında pozitif ve anlamlı bir ilişki tespit edilmiştir. Alan yazında özdeşleşme kavramı ile kişinin işini anlamlı bulmasının yakından ilgili olduğunu görüyoruz (Baklaieva,2016). Sözgelimi Goldenhuys ve diğerleri (2014) işin anlamlılığın çalışmaya tutkunluğu tahmin ettiğini belirtmiştir. Bu bağlamda araştırmamızın öznesini oluşturan sağlık çalışanların anlamlı bir meslek icra etmeleri onların işleri ile özdeşleşmesini ve de çalışmaya tutkunluğa eğilimli olmalarını kolaylaştırmaktadır. O halde araştırma kısıtları dâhilinde örgütü ile özdeşleşmiş bireylerin işlerini başarmak veya amaçlara ulaşmak için gerekli olan canlılığı, odaklanmayı ve adanmışlığı gösterebileceklerini rahatlıkla söyleyebiliriz. Bu sonuç Türkoğlu (2019) çalışması ile benzerlik göstermektedir. Türkoğlu (2019) araştırmasında örgütsel özdeşleşme ile çalışmaya tutkunluk arasında pozitif ilişki olduğunu tespit etmiştir. Ayrıca Aktaş (2019) doktora tezinde örgütsel özdeşleşme ile işe adanma arasında aynı yönde ilişki tespit etmiştir.

Özdeşleşememe, bireyin kimliği ile örgütün kimliği arasındaki uçurumu ifade etmektedir. Birey ekonomik, örgütsel ve kişisel nedenlerden dolayı işten ayrılmaya niyetlenebilmektedir. Alan yazında çalışmaya tutkun insanların psikolojik sorunlarının daha az ve işten ayrılma niyetlerinin daha düşük olduğu görülmüştür (Turgut, 2010). Araştırmamızın ikinci aşamasında "işten ayrılma niyeti" ile "çalışmaya tutkunluk" kavramının bağımsız değişkenleri "canlılık", "odaklanma" ve "adanmışlık" boyutları regresyon analizine tabi tutulmuştur. Sonuçta "işten ayrılma niyeti" ile "canlılık" ve "adanmışlık" arasında beklenildiği üzere negatif ve anlamlı ilişki tespit edilirken; "işten ayrılma niyeti" ile "odaklanma" boyutu arasında yeteri kadar güçlü bir ilişki tespit edilmemiştir. Bu bağlamda işten ayrılma niyeti olan bireylerin işlerini icra ederken canlı olmadıkları ve kendilerine işlerine adayamadıklarını söyleyebiliriz. Bu sonuç Alfes ve diğerleri (2013) ile Schaufeli ve Bakker (2004) araştırma sonuçları ile benzerlik göstermektedir. Araştırmacılar işten ayrılma niyeti ile çalışmaya tutkunluk arasında anlamlı ve negatif ilişki tespit etmişlerdir. Bitkinlik ve işe adanmamak bireydeki tükenmişlik belirtileri olabileceği gibi kişinin örgütü ile özdeşleşememe sonucu da ortaya çıkabilmektedir. Zira birey örgütü ile tümü ile özdeşebileceği gibi, örgütün bir kısmı veya bir yönü ile de özdeşim kurabilir. Bununla birlikte örgütü ile hiçbir şekilde özdeşleşmeyebilir. Bunun nedeni bireysel faktörler olabileceği gibi bu faktörlerin kişi de oluşturduğu tükenmişlik de olabilir. Özellikle iş kaynaklarının bireyin talepleri ile uyuşmaması bireyde zamanla hoşnutsuzluk ve tükenmişlik oluşturabilir. Nitekim Schauefeli ve Bakker (2004) çalışmaya tutkunluğun işten ayrılma niyeti ile iş kaynakları arasında aracı değişken olduğunu ileri sürmüştür. Alan yazında çalışmaya tutkunluk tükenmişlik kavramının zıt yönü olarak kabul edilmektedir (Çankır ve Yener, 2017). Nitekim Schaufeli ve diğerleri (2002) çalışmaya tutkunluk ile tükenmişlik arasında negatif ilişki tespit etmiştir.

Araştırmamızda beklenenin aksine "işten ayrılma niyeti" ile "odaklanma" arasında negatif ve anlamlı bir ilişki vardır hipotezi desteklenmemiştir. Aslında hipotezde öne sürülen ilişki tam olarak sınır değerlerde oluştuğu için hipotezin desteklenmediği kabul edilmiştir.'Odaklanma' bireyin çalışırken kendini kaybetmesi ve işine yoğunlaşmasını ifade etmektedir. Odaklanma her ne kadar Csikszentmihalyi (1990) "akış" kavramına benzese de küçük bir nüansla ondan farklıdır. Akış 
kavramı bireyin dikkatini, amaçlarına ulaşmak için özgürce ve keyifle harcadığı durumlardır. Akış durumları genellikle oteletik kişilik özelliklerine sahip insanlarda görülür ve çok daha genel bir heyacanı temsil etmektedir. Oteletik kişiler eylemleri kendileri için yaparlar. Bir fayda beklentileri yoktur. Eylemin kendisi onlar için bir ödüldür. Oysa çalışmaya tutkunluk kavramının odaklanma boyutunun deneyim alanı iş yeri ile sınırlıdır. Pozitif bir kişilik özelliği olarak öne çıkan odaklanma, işkolikliğin aksine zihinsel bir yoğunluk ve sükûnet gerektirmektedir (Turgut, 2010). Odaklanma halinin çalışma ortamında gerçekleşmesi için işin gereklilikleri ile meslek becerileri arasında denge veyahut yüksek düzeyde beceri gerektiren bireyler gerekmektedir. Bu yüzden Hakanen ve diğerleri (2008) canlılık ve adanmışlık boyutlarını çalışmaya tutkunluğun iki temel boyutu olarak ele olarak ele almış ve odaklanmayı göz ardı etmiştir.

\section{Sonuç ve Öneriler}

$\mathrm{Bu}$ araştırma ile bireyin örgütü ile özdeşleşmesinin veya özdeşim kuramamasının (işten ayrılma niyetinin) çalışmaya tutkunluğun öncülü olduğu ortaya koyulmuştur. Örgütsel özdeşleşme kavramının çalışmaya tutkunluğun öncülü olması örgütte daha az beşerî sorun ve daha düşük ayrılma niyeti demektir. Bu aynı zamanda daha güçlü bağ ve daha yüksek performans anlamına gelmektedir. Zira işine tutku ile sarılan birey böylece kendi potansiyelini de ortaya koyma firsatı bulmaktadır. İşi hem bireyin motivasyon kaynağ hem de kendini ifade etme şekli olmuştur. Bu bağlamda bireyin içinde bulunduğu örgüt ile özdeşim seviyesinin onun çalışmaya tutkunluk seviyesini belirlemede etkili olduğunu rahatlıkla söyleyebiliriz.

Özdeşleşme sadece birey adına değil, örgüt adına da istenen bir durumdur. Çünkü iki taraflı bir özdeşleşme neticesinde doğal olarak yine iki taraflı ekonomik ve sosyal kazanç ortaya çıkmaktadır. Böylece örgüt kısa ve uzun soluklu enerji kazanmaktadır. Fakat burada unutulmaması gerekir ki çift taraflı kuvvetli bir özdeşim yine çift taraflı yüksek performansa bağlıdır. Bu yüzden araştırmamıza özne olan kavramların gelişim sürecinden yararlanarak aşağıdaki öneriler yöneticilere sunulmuştur.

- Örgütün saygınlığını artıracak eylemler yapılmalıdır. Birey kendi saygınlığını artırmak için saygın bir şirkette çalışmak eğilimindedir.

- Örgüt, kendisini başka örgütlerle ayırt edecek uygulamalar sergilemelidir. Yüksek ayırt edicilik yüksek özdeşleşme doğurmaktadır.

- Örgüt, kendi misyonu ve vizyonu ile özdeşleşen bireyler istihdam etmelidir.

- Örgüt, insan kaynakları seçiminde bireyin rasyonel talepleri ile iş kaynaklarının örtüşmesine dikkat etmelidir.

- Örgüt, katılımcı bir yönetim anlayışı benimsemelidir.

- Örgüt, bireye ekonomik değil, sosyal bir varlık olarak bakmalıdır.

- Örgüt, bireye kendini fiziksel ve ruhsal olarak ifade edebileceği bir örgütsel iklim ve kültür ortamı oluşturmalıdır.

- Örgüt, bireye kariyerini geliştirme firsatı vermelidir. Kariyer fırsatları objektif kriterlere bağlı olmalıdır.

- Örgüt içerisinde yönetici ile çalışan arasında güven tesis edilmelidir.

- Örgütsel adaletten taviz verilmemelidir. Eşit işe eşit ücret alınması sağlanmalıdır.

- Yetenekli bireylerin yeteneklerini geliştirebileceği ve kendini gerçekleştirebileceği bir sistem kurulmalıdır.

- Örgüt yönetiminde çalışanlara koçluk yapabilecek, ilham verebilecek, onları motive edebilecek liderler benimsenmelidir. 
Örgütsel Özdeşleşme ile işten ayrılma niyeti üzerine her ne kadar alan yazında yeterince çalışma bulunsa da bu kavramların pozitif örgütsel davranış (çalışmaya tutkunluk) ile ilişkisi üzerine alan yazında hala büyük bir boşluk vardır. Bu çalışma ile söz konusu boşluğun araştırma kısıtları dâhilinde bir nebze doldurulduğuna inanıyoruz.

\section{Kaynakça}

Ak, B. (2018)." Turnover intention influencing factors of employees: An empirical work review". Journal Of Entrepreneurship \& Organization Management,7(3), 1-7.

Aktaş, K. (2019).” İşgörenlerin adanmışlık düzeyi ve örgütsel özdeşleşme ilişkisinin performans algısına etkisini belirlemeye yönelik bir araştırma". İnönü Üniversitesi Sosyal Bilimler Enstitüsü, Doktora Tezi.

Alfes, K., Shantz, A.D., Truss, C.ve Soane, E.C. (2013)." The link between perceived human resource management practices, engagement and employee behaviour: a modarated mediation model". The International Journal Of Human Resource Management, 24(2), 330352.

Aliyev, Y. (2014).” Örgütsel sosyalleşme ve örgütsel özdeşleşme arasındaki ilişki: Bir araştırma”. Atatürk Üniversitesi, Sosyal Bilimler Enstitusü İşletme Anabilim Dalı, Yüksek lisans tezi.

Aronson, E. Wilson, T.D. ve Akert, R.M. (2012).” Sosyal Psikoloji”. Kaknüs yayınları,1.Basım.

Ashforth, B.E. ve Mael, F. (1989)." Social identity theory and the organization". Academy Of Management Review,14(1), 20-39.

Ashforth, B.E. Harrison, S.H.ve Corley, K.G. (2008)." Identification in organizations: An examination of four fundemental questions". Journal Of Management,34(3), 325-374.

Bakker, A. B. ve Demerouti, E. (2008). "Towards a model of work engagement". Career Dev. Int. $13,209-223$.

Bakker, A. B. Demerouti, E., ve Sanz-Vergel, A. I. (2014). "Burnout and work engagement: The JDR approach". Annual Review Of Organizational Psychology And Organizational Behavior, 1(1), 389-411.

Bakker, A. B. Schaufeli, W. B., Leiter, M. P. ve Taris, T. W. (2008). "Work Engagement: An Emerging Concept in Occupational Health Psychology". Work and stress, 22(3), 187-200.

Baklaiva, O. (2016)." The relationship among meaningfulness of work, work engagment and intention to leave". ISM University Of Management And Economics. Master thesis.

Bergami, M.ve Bagozzi, R.P. (2000). "Self-categorization, affective commitment and group selfesteem as distinct aspects of social identity in the organization". British Journal Of Social Psychology, 39(4), 555-557.

Carr, A. (2016).” Pozitif psikoloji”. Kaknüs Yayınları:598,1.basım.

Csikszentmihalyi, M. (1990).” Mutluluk bilimi: Akış". Buzdağı Yayınevi.

Çankır, B.ve Yener, S. (2017).” İş’te pozitif davranış”. Çizgi Kitapevi Yayınları:809.

Demircioğlu, Y. ve Giritli, F.H. (2015). "Organizational identification and turnover intention of employees in the turkish construction industry." Paper presented at the going north for sustainability: Leveraging knowledge and innovation for sustainable construction and development". London South Bank University. 
Demirtaş, H.A. (2003). “Sosyal kimlik kuramı, temel kavram ve varsayımlar”. İletişim Araştırmaları, $1(1), 123-144$.

Drzensky, F. ve Van Dick, R. (2009). "Organizational identification and organizational change,". The psychology of organizational change, Chapter prepared for: S. Oreg, A. Michel, and R. Todnem, Cambridge university press), 275-297.

Durmuş, B. Yurtkoru, S., ve Çinko, M. (2011). "Sosyal bilimlerde SPPS'le veri analizi”. Beta Yayınları.

Dutton, J.E. Dukerich, J.M. ve Harquail, C.V. (1994). "Organizational images and member identification”. Administrative Science Quarterly, 39(2), 239-263.

Edwards, M. ve Peccei, R. 2007, 'Organizational identification: Development and testing of a conceptually grounded measure'. European Journal Of Work And Organizational Psychology, 16(1), 25-57.

Eniç, D. (2019). "Karşıtlıktan ortaklığa: Önyargıyı azaltma yolu olarak yeniden sınıflandırma". Nesne, 7(14), 102- 126.

Gautam, T. Van Dick, R. ve Wagner, U. (2004). "Organizational identification and organizational commitment: Distinct aspects of two related concepts". Asian Journal Of Social Psychology, 7 (3), 301-315.

Geldenhuys, M. Łaba, K.ve Venter, C.M. (2014). "Meaningful work, work engagement and organisational commitment". SA Journal of Industrial Psychology/SA Tydskrif vir Bedryfsielkunde, 40(1), 1-10.

Hakanen, J.J. Schaufeli, W.B.ve Ahola, K. (2008).” The job demands-reseources model: A threeyear cross-lagged study of burnout, depression, commitment and work engagement". Work \& Stress,22(3), 224-241.

Kahn, W.A. (1990). 'Psychological conditions of personal engagement and dis-engagement at work". Academy Of Management Journal, 33(4), 692-724.

Kahn, W.A. (1992)." To be fully there: Psychological presence at work". Human Relations, 45(4),321-349.

Lee E. S. Park T. Y. \& Koo B. (2015). "Identifying organizational identification as a basis for attitudes and behaviors: a meta-analytic review". Psychological Bulletin, 14(5), 1049-1080.

Mael, F. ve Ashforth, B.E. (1992)." Alumni and their alma mater: A partial test of the reformulated model of organizational identifacation". Journal Of Organizational Behaviour, 13(2), 103123.

Mael, F.A.ve Tetrick, L.E. (1992).” Identifying organizational identification". Educational and Psychological Measurement,52, 813-824.

Mamatoğlu, N. (2010). 'Lider davranışları algıları ve örgütsel kimliklenme boyutları arasında çalışanın kişilik özelliklerinin düzenleyici rolü’. Türk Psikoloji Dergisi, 25(65), 82-97.

Özdemir, A. (2013)." Yönetim biliminde ileri araştırma yöntemleri ve uygulamalar". Beta Yayınları.

Peterson, C. Park, N.ve Seligman, M.E. P (2005)." Orientations to happiness and life satisfaction: The full life versus the empty life". Journal Of Happiness Studies, 6, 25-41.

Polat, M. ve Meydan, C.H. (2010).” Örgütsel özdeşleşmenin sinizm ve işten ayrılma niyeti ile ilişkisi üzerine bir araştırma”. Savunma Bilimleri Dergisi, 9(1), Mayıs, 145-172. 
Riketta, M. ve Van Dick, R. (2005). "Foci of attachment in organizations: A meta-analytic comparison of the strength and correlates of workgroup versus organizational identification and commitment". Journal Of Vocational Behavior, 67(3), 490-510.

Robinson, D. Perryman, S. \& Hayday, S. (2004). “The Drivers of Employee Engagement”. Brighton: Institute For Employment Studies.

Schaufeli, W. B. Salanova, M., González-Romá, V., ve Bakker, A. B. (2002). “The measurement of engagement and burnout: A two sample confirmatory factor analytic approach". Journal Of Happiness Studies, 3(1), 71-92.

Schaufeli, W.B. ve Bakker, A.B. (2004). "Job demands, job resources, and their relationship with burnout and engagement: A multi-sample study". Journal Of Organizational Behavior, 25(3), 293-315.

Schaufeli, W.B. (2013). "What is engagement? In C. Truss, K. Alfes, R. Delbridge, A. Shantz ve E. Soane (Eds.)". Employee Engagement In Theory And Practice. Routledge.

Schaufeli, W.B. (2012).” Work engagement. What do we know and where do we go?". Romanian Journal Of Applied Psychologhy, 14(1), 3-10.

Schaufeli, W.B. Salanova, M. Gonzales-Roma, V., ve Bakker, A.B. (2002).” The measurement of engagement and burnout: A two sample confirmatory factor analytic approach". Journal Of Happines Studies, 3(1), 71-92.

Solomon, J. ve Casey, A. (2017).” A hierarchical model of organizational identification”. Journal Of Organizational Psychologhy, 17(3), 93-111.

Spears, R. ve Otten, S. (2012).” Ayrımcılık: Tajfel'in minimal grup modeli çalışmalarını yeniden değerlendirmek". Sosyal Psikoloji Klasik Çalışmaları yeniden değerlendirmek (Joanne R. Smith ve S. Alexander Haslam), Nobel Akademik Yayınc1lık, 1.Basım (2016), Ankara

Tajfel, H. Billig, M.G. Bundy, R.P.\&Flament, C. (1971)." Social categorization and intergroup behaviour". European Journal of social psychologhy,1(2), 149-178.

Tafjel, H. ve Turner, J.C. (1986). "Social identity theory of intergroup behavior". In S. Worchel \& W.G. Austin (Eds.), Psychology of Intergroup Relations (pp. 276-293). Nelson-Hall.

Tak, B. ve Aydemir, B.A. (2004).” Örgütsel özdeşleşme üzerine iki görgül çalışma".12.Ulusal Yönetim ve Organizasyon Kongresi Bildiri Kitabı, 27-29 Mayıs 2004, 59-63.

Tuna, M ve Yeşiltaş, M. (2014).” Etik İklim, işe yabancılaşma ve örgütsel özdeşleşmenin işten ayrılma niyeti üzerindeki etkisi: Otel işletmelerinde bir araştırma". Anatolia: Turizm Araştırmaları Dergisi,25(1), 105-117.

Tosun, M. (1981). “Örgütsel Etkililik”. Türkiye ve Ortadoğu Amme İdaresi Enstitüsü Yayınları $\mathrm{Nu}: 196$.

Tsuchiya, Y. (2017).” A critical review of organizational identification: Introducing identity work to examine dynamic process". Journal Of Organizational Culture, Communications And Conflict, 21 (2), 1-10.

Turgut, T (2011).” Çalışmaya tutkunluk: İş yükü, esnek çalışma saatleri, yönetici desteği ve iş-aile çatışması ile ilişkileri”. Atatürk Üniversitesi İktisadi ve İdari Bilimler Dergisi, 25 (3-4), 155 179.

Turgut, T. (2010).” Çalışmaya tutkunluk, kurumlarda iyilik de var / Editör: Güler İslamoğlu”. Nobel Yayın Dağıtım, 1.Baskı. 
Türkoğlu, G. (2019).” Relationship between organizational identification and work engagement, job satisfaction and turnover intention in family firms". Kadir Has University, Master Thesis.

Van Dick, R. Wagner, U. Stellmacher, J. Christ, O. (2004). "The Utility of a Broader Conceptualization of Organizational Identification: Which Aspects Really Matter?". Journal Of Occupational And Organizational Psychology. 77, 171-191.

Witting, M. (2006). "Relations Between Organizational Identity, Identification, and Organizational Objectives: An Empirical Study in Municipalities". Universiteit Twente, Enschede. 